\title{
THE INFLUENCE OF CREDIBILITY AND ATTRACTIVENESS OF BEAUTY VLOGGER AS A CELEBRITY ENDORSER ON CONSUMER PURCHASE INTENTION
}

\author{
Hikmawati \\ Management Department, Faculty of Economics and Business \\ Universitas Muhammadiyah Malang \\ Email : hikmamchtr@gmail.com
}

\begin{abstract}
This study aims to identify the effect of beauty vlogger's credibility and attractiveness on purchase intention and find the most influential variable. A quantitative approach using survey (questionnaire) was used. The population in this study was 41.517 viewers of Abel Cantika's vlog titled "Demo dan Review the Body Shop New Hair Care Fuji Green Tea". 100 samples were selected using purposive sampling technique. The results of this study found that both credibility and attractiveness of the endorser significantly influenced purchase intention, the later was found to be the most influential variable.
\end{abstract}

Keywords: attractiveness, beauty vlogger, celebrity endorser, credibility, purchase intention.

\section{INTRODUCTION}

Purchase intention is a motivation for someone to own an item he/she wished to have. Consumer interest and behavior are important for companies because they reflect the companies' marketing program (Ferrinadewi, 2008).

Various types of promotion are carried out by companies to profitably influence the minds and feelings of consumers in order to get a positive response.Hence,consumers will have good assessment or interest in buying the goods or using services offered by the companies.

Companies need to choose creative ways to advertise their products in order to attract consumers' attention and create brand preference. One of the creative ways to do it is by using endorsers.

Endorsers can involve celebrities, experts, ordinary people, executives, employees or spokesperson (Schiffman and Kanuk, 2008). There are two important aspects commonly possessed by a celebrity endorser, namely credibility and attractiveness.

Credibility and attractiveness play essential roles in effective endorsement. While credibility is related to consumer trust, attractiveness refers to one's appeal in relation to the concept of physical attractiveness conformed by certain groups (Shimp, 2003). Credibility refers to the tendency to have confidence in someone as a source of 
information or representative of certain brands who is trustworthy, especially to the consumers. The perception toward the credibility of endorsers is determined subjectively through individual assessment.

Consumer perception toward endorsers seems more important than their actual quality in presenting the products they advertise. This affects in how these endorsers perceive credibility. Either the endorsers are celebrity or non-celebrity, they are expected to bring positive influence to encourage positive responses from the consumers.

Attractiveness is a positive view of a person not only based on his/her physical appearance but also based on other characteristics such as personality and athletic skills (Ermec, 2014). In his research, Isaac (2008) mentioned that endorsers who were more attractive tended to encourage more purchase intention compared to those who were less attractive. Many fashion and beauty industries use beauty vloggers as a celebrity supporter (celebrity endorser) to promote their products using beauty vlog as the medium. Beauty vlogger is someone who makes and uploads videos about beauty. The Body Shop is one of the brands working together with several Indonesian beauty vloggers in promoting its products. One of them is Abel Cantika, where she advertised The Body Shop product in her beauty vlog titled "Demo dan review The Body Shop New Hair Care Fuji Green Tea".

This current study seeks to identify whether the two variables possessed by a beauty vlogger as a celebrity endorser, namely credibility and attractiveness, have an influence on consumer purchase intention. It also tries to analyze which of these two variables have more influence on consumers' decision to buy certain products.

\section{LITERATURE REVIEW}

Schiffman and Kanuk (2010) define consumer behavior as the behavior shown by consumers in finding, buying, using, evaluating, and enjoying the products and services they hope will satisfy their needs. According to Nurmala (2008), buying intention is a tendency to feel interested or motivated to get and possess goods and services. Therefore, one's decision to buy something is generally preceded by purchase intention. The consumers' purchase intention can come from their positive attitudes toward the products they wished to buy, which also reflects their positive assessment of the product (Noor et al., 2013).

Pujiyanto (2001) defines advertising as a means of communication through various media at a certain price intended to introduce a product so that people are interested in and agree with the message delivered by the advertisement. Kotler (2013) adds that advertising is any form of nonpersonal presentation and promotion of ideas, goods or services by a sponsor that requires payment.

Shimp (2003) mentioned that using celebrity endorser means using celebrities as commercial stars in various media, including print, social media, and television. The celebrity endorsers are expected to become spokespersons of the brand so the consumers will remember the brand 
much more easily, be aware of its existence, and are willing to buy the product.

Credibility refers to the tendency to have confidence in someone as a source of information or representative of certain brands who is trustworthy, especially to the consumers. Therefore, whether the endorsers are a celebrity or not, they are expected to have a positive influence and attract more positive responses from the consumers.

Biswas' study in 2006 revealed that using trustworthy \& professional endorsers could reduce consumers' perceived risk regarding technology products, so as to increase consumers' interest to buy these products. Similar results were also found in studies conducted by Munggaran \& Azis (2015) and Saputra (2016), which shown that the credibility of endorsers had a significant influence on consumer purchase intention. Based on the results of the afore mentioned studies, the researcher in this current study proposes hypothesis 1 (H1), which states that the credibility of endorsers has a significant and positive influence on consumer purchase intention.

Attractiveness is more than physical attributes, although physical appearance can be important too. However, being attractive also means that one has striking features or qualities worthy to the public (Shimp, 2003).

In their study, Munggaran and Azis (2015) found that the attractiveness of endorsers has a significant and positive influence on consumer purchase intention. Other studies in this area by Pratiwi (2015) and Pontoh (2016) also yielded similar results. Hence, based on the results of these previous studies, hypothesis $2(\mathrm{H} 2)$ is proposed. This hypothesis states that the attractiveness of endorsers has a significant and positive influence on consumer purchase intention. The two hypotheses proposed as seenon the Figure 1 as follows:

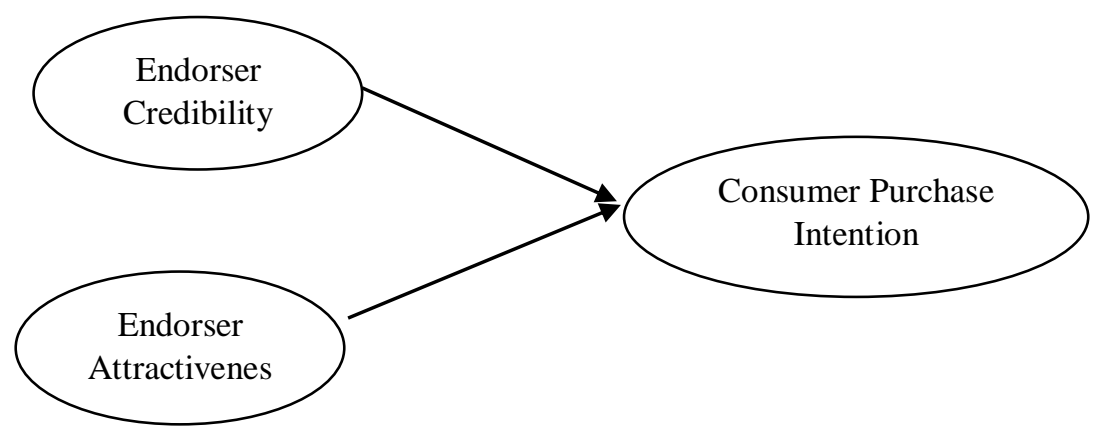

Figure 1. Research Outline

\section{METHOD}

This is a quantitative study with a survey method using questionnaire. The population of this study was the viewers of the video titled "Demo dan review The Body Shop New Hair
Care Fuji Green Tea" on Abel Cantika's Youtube channel. 100 samples were recruited in this study. The number is based on the minimum number of samples for descriptive research, which is 100 
respondents (Widayat, 2004). Nonprobability sampling using purposive sampling technique was used. The respondents were chosen based on the following criteria: a) Viewers of the vlog "Demo dan review The Body Shop New Hair Care Fuji Green Tea" on Abel Cantika's Youtube channel, b) female, and c) between 17 and 31 years of age. The data used was primary data, which was obtained directly from the answers of questionnaires or list of questions intended for the consumers.

There are three variables in this study, namely endorser credibility, endorser attractiveness, and consumer purchase intention. Firstly, endorser credibility (X1) is the reliability of the endorsers who is considered professional or has decent knowledge of a particular product so as to influence and convince the audience about the product they are promoting. The indicators include: (a) being objective in presenting the product, (b) having confidence in beauty vlogger, (c) having knowledge of the product, (d) having good ability in delivering messages to consumers, and (e) having experience related to the product or brand.

Secondly,

endorser attractiveness (X2) is the ability of the endorsers to attract the attention of the audience through physical appearance, or through respects they earned for reasons other than physical attractiveness (e.g. having similar characteristics or being in similar circumstances to the audience). The indicators of beauty vlogger attractiveness include: (a) physical appearance, (b) charisma, (c) communication skill, (d) similar skin problems to the audience.

Thirdly, consumer purchase intention (Y) is related to the consumer's plan to purchase a particular product and how many products to buy. The indicators include: (a) showing interest in finding information about the product, (b) considering buying, (c) showing intention to buy (Jalilv and, 2012). All of these variables were measured using a 5 -point Likert scale.

Multiple regression analysis method was used in the data analysis upon meeting the requirements of validity, reliability, and classical assumptions. Multiple regression analysis is used to determine how much impact endorser credibility and attractiveness have on consumer purchase intention. The hypothesis test was performed through the following steps: (1) Simultaneous effect test $(\mathrm{F})$, to see whether all the independent variables in the model have simultaneous effect on the dependent variable, (2) Partial effect test $(t)$, to see how much influence of each independent variable on explaining the variation of the dependent variable.

The coefficient of determination $\left(R^{2}\right)$ was also calculated to measure the ability of the model to explain the variation of the dependent variable. The coefficient of determination is between zero and one. Finally, the independent variable with the most contribution to the dependent variable was determined using standardized coefficients beta at a $95 \%$ confidence level or a significant level of 5\% (Ghozali, 2013). 
RESULTS AND DISCUSSION

The result of multiple regression analysis will be shown as in the

Table 1:

Table 1. Results of Multiple Regression Analysis

\begin{tabular}{cccccc}
\hline \multirow{2}{*}{ Independent Variable } & \multirow{2}{*}{ Variabel Dependent } & \multicolumn{2}{c}{ Coefficient } & \multirow{2}{*}{ T. value } & \multirow{2}{*}{ Sig. } \\
\cline { 3 - 4 } Constant & B & $\beta$ & & \\
\hline & Purchase intention & 2.979 & & 2.238 & 0.027 \\
Endorser credibility (X1) & $(Y)$ & 0.191 & 0.223 & 2.267 & 0.026 \\
Endorser attractiveness (X2) & & 0.225 & 0.256 & 2.515 & 0.014 \\
\hline
\end{tabular}

Based on Table 1, the following multiple linear regression equation was obtained: $\mathrm{Y}=2.979+$ $0.191 \mathrm{X} 1+0.225 \mathrm{X} 2$. This equation shows that the regression coefficient of each independent variable has positive value, which means that both credibility and attractiveness variables positively influence consumer purchase intention. The results of the simultaneous test (Ftest) are shown in Table 2 below.

Table2. Results of Simultaneous test (F test)

\begin{tabular}{ccccc}
\hline Variable & F value & F statistic & Sig. & Interpretation \\
\hline $\begin{array}{c}\text { Endorser credibility } \\
\text { (X1) \& Endorser } \\
\text { attractiveness (X2) }\end{array}$ & 10.188 & 3.09 & 0.000 & Significant \\
\hline
\end{tabular}

Table 2 shows $F$ value of 10.188 with a significant level of 0.000 and $F$ statistic (at alpha $5 \%$ ) of 3.09 , in which $\mathrm{F}$ value $>\mathrm{F}$ statistic with a significance level of 0.000 $<0.05$. It means that simultaneously, both independent variables (credibility and attractiveness) have positive and significant effect on consumer purchase intention. If probability value $>0.05$ then $\mathrm{Ho}$ is accepted, while probability value $<0.05$ means that $\mathrm{Ho}$ is rejected (Gozhali, 2013).

The t-test was conducted by following the criteria adopted from Gozhali (2013). It was stated that if T value > $\mathrm{T}$ statistic and $\mathrm{Sig}<0.05$ (alpha) then the independent variable has an effect on the dependent variable. On the contrary, if $\mathrm{T}$ value
$<\mathrm{T}$ statistic and Sig >0.05 (alpha) then the independent variable does not affectthe dependent variable. The results of the partial influence test ( $t$ test) in this study have been shown in Table 1.

Based on Table 1, the credibility variable (X1) has a significance value of 0.026 or $<0.05$, thus $\mathrm{Ho}$ is rejected and $\mathrm{H} 1$ is accepted. It shows that the credibility variable (X1) alone has a significant and positive effect on consumer purchase intention. In this case, the more credible a beauty vlogger or a celebrity endorser in influencing consumers subjectively through individual evaluation, the higher the consumer purchases intention. That said, the first hypothesis is accepted. The results of this study are in line 
with the previous studies conducted by Biswas (2006), Munggaran \& Azis (2015), and Saputra (2016). Similarly, the significance value of the attractiveness variable (X2) shown in table 1 is 0.014 or $<0.05$, so Ho is rejected and $\mathrm{H} 2$ is accepted. It means that attractiveness variable (X2) alone has significant and positive influence on consumer purchase intention. In other words, the more attractive the endorser chosen by a brand, the higher the consumer purchase intention, thus $\mathrm{H} 2$ is accepted. This result is in accordance with previous studies by Mungg aran and Azis (2015), Pratiwi (2015), and Pontoh (2016), which revealed similar results to this current study. From the regression model obtained, it can be seen that the beta coefficient of the attractiveness variable has greater value compared to the credibility variable (0.225). It means that attractiveness variable has dominant influence on consumer purchase intention.

In other words, the attractiveness of beauty vlogger Abel Cantika, who is a celebrity endorser of The Body Shop New Fuji Green Tea Hair Care, is more influential in encouraging the respondents' (female consumers') purchase intention. The result of the coefficient of determination $\left(R^{2}\right)$ is shown in Table 3 below.

Table 3. Result of Coefficient of determination $\left(\boldsymbol{R}^{2}\right)$

\begin{tabular}{ccc}
\hline $\mathrm{R}$ & $R$ Square & Adjusted $R$ Square \\
\hline 0.603 & 0.364 & 0.338 \\
\hline
\end{tabular}

Table 3 shows that the coefficient of determination $\left(R^{2}\right)$ obtained is 0.364 or $36.4 \%$. This means that variations in consumer purchase intention can be explained by independent variables (credibility and attractiveness) is $36.4 \%$, while the rest is explained by other variables not examined in this study.

\section{CONCLUSION}

The credibility and attractiveness variable of beauty vlogger has a significant and positive effect on female consumers'purchase intention. The attractiveness variable has greater influence compared to the credibility variable, which can be seen from the results of the t-test indicating attractiveness being the dominant variable.

Apart from the results obtained, there might be other factors influencing the respondents. For instance, prior to completing the questionnaire, the consumers might have watched beauty vlogs by other beauty vloggers and had not enjoyed them, which might have resulted in respondents being less objective in filling out the questionnaire. Besides, this study has not included variables on other aspects that might influence and improve the results. One of the mediating variables that could be included is attitude, which might have an effect on purchase intention. Other variables or indicators that use celebrity endorser as a promotional tool could also be included 


\section{REFERENCES}

Ermec Aysegul., Ozlem Catli., dan Sezer. 2014. Examining the effect of endorser credibility on the consumers' buying intentions: an empirical study in Turkey. International Review of Management and Marketing.vol. 4, no. 1 : 66-77.

Ferrinadewi, Erna. 2008. Merek dan psikologi konsumen: implikasi pada strategi pemasaran. Yogyakarta: Graha Ilmu.

Ishak, Asmai. 2008. Pengaruh penggunaan selebriti dalam iklan terhadap minat beli konsumen.Jurnal Siasat Bisnis: 71-88.

Kotler, Philip dan Kevin Lane Keller. 2012. Manajemen pemasaran. Jilid 1. Jakarta: PT. Indeks.

Kotler, Philip. dan Kevin Lane Keller. 2013.Manajemen

pemasaran, Jilid II,. Jakarta: Erlangga.

Nurmala. 2008. "Pengaruh iklan televisi terhadap minat beli

sabun mandi pada mahasiswa fakultas ekonomi universitas malikussaleh."

Jurnal

Terakreditasi SK Dirjen Dikti No. 43/Dikti/Kep/2008. ISSN:1693-5241.

Schiffman, Leon. \& Lazar L Kanuk. 2008. Perilaku konsumen. Edisi ketujuh. Jakarta: PT.Indeks.

Shimp, Terence. A. 2003. terj. Revyani Sahrial, Diah Anikasari. Komunikasi pemasaran terpadu dalam periklanan dan promosi, Edisi

5. Jakarta:Salemba Empat.

Widayat. 2004. Metode penelitian pemasaran. Malang : CV. Cahaya Press.

Ghozali, Imam. 2013. Aplikasi analisis multivariate dengan program IBM SPSS 21 update PLS regresi. Semarang: Badan Penerbit Universitas Diponegoro.

Biswas, D. et al. 2006. The differential effects of celebrity and expert endorsements on consumer risk perceptions. Journal Of Advertising, Vol. 35 No. 2, pp. 17-31.

Jalilvand, R, 2012, The effect of electronic word of mouth on brand image and purchase intention. Journal of Marketing Intelegence and Planning, Vol 30. Iss:4, Januari, hal 5-5.

Munggaran, Aria Putra dan Elvira Azis. 2015. "Pengaruh endorser credibility terhadap minat beli konsumen". Jurnal FEB Universitas Telkom. Vol.2. No.3. ISSN 2355-9357. Page 2691.

Noor, M. N. M., Jayashree, S. dan Hishamuddin, I. 2013. Malaysian consumers' attitude towards mobile advertising and its impact on purchase intention-a- structural equation modelingapproach.Internationa $l$ Journal Of Economics And Statistics, Issue 3, Vol. 1. Pontoh, Y.G. 2016.Pengaruh celebrity endorser (Pevita Pearce) terhadap minat beli 
konsumen pada produk garnier bb cream di fakultas ekonomi dan bisnis Universitas Lampung(unpublished thesis) FEB. Universitas Lampung.

Pratiwi, Indri, dan Nadya Moeliono. 2015. "Pengaruh celebrity endorserMaudy Ayunda terhadap daya beli produk teh Javana (a society study in Bandung)". Jurnal Komunikasi dan Bisnis Universitas Telkom, Vol.2 No.3, ISSN 2355-9357. Page 3576.

Saputra, Y.A. 2016. Pengaruh kredibilitas endorser raisa terhadap minat beli konsumen pada iklan Pond's white beauty (studi kasus pada mahasiswi FEUII) (unpublished thesis). FE Universitas Islam Indonesia. 